How to Cite

Ramlan, -, Rahman, A., Faisal, -, \& Sutrisno, M. (2019). Land use and environment physical condition on sedimentation and water discharge of lindu lake watershed. International Journal of Chemical \& Material Sciences, 2(1), 1-7.

https://doi.org/10.31295/ijcms.v2n1.71

\title{
Land Use and Environment Physical Condition on Sedimentation and Water Discharge of Lindu Lake Watershed
}

\author{
Ramlan \\ Mulawarman University, Indonesia \\ Corresponding author email: iss_palu@yahoo.com
}

\author{
Abdul Rahman \\ Tadulako University, Indonesia \\ Email: mankuntad@yahoo.com \\ Faisal \\ Tadulako University, Indonesia \\ Email:faisalkono@gmail.com \\ Muhammad Sutrisno \\ Tadulako University, Indonesia \\ Email: sultrisno@yahoo.com
}

\begin{abstract}
Lindu lake sub-watershed has harmed by various human activities which do not pay attention to environmental sustainability principles. This research aims to know the influence of land use area and environment physical condition on sedimentation and water discharge in Lindu lake sub-watersheds. This research uses survey and non-experimental method on 3 rivers which are Langko (P1), Wongkodono (P2), and Kati (P3). The dependent variable in this research is land use area (area of the garden, shrubs, rice field, forest, and settlement) and environment physical condition (catchment area and average annual rainfall) and the independent variables are sedimentations and water discharge. The used statistical analysis is a multiple regression model. The result shows that the wider shrubs area $\left(X_{2}\right)$ reduces sedimentation $\left(Y_{1}\right)$ and increases water discharge $\left(Y_{2}\right)$. Each addition of one shrub unit will decrease sediment in amount of $0,208 \mathrm{mg} / \mathrm{L}$ and affects water discharge an amount of $0,258 \mathrm{~m}^{3} / \mathrm{sec}^{-1}$ with regression equation $Y_{1}=185,903-0,208 X_{2}-587,269 X_{8}$ and $Y_{2}=6,854+0,258 X_{2}-71,708 X_{8}$. As for the bigger river shape coefficient $\left(X_{8}\right)$ so the smaller water discharge average. Hence, each reduction of one river shape coefficient unit will affect water discharge in the amount of 71,708 $\mathrm{m}^{3} / \mathrm{sec}^{-1}$. It can be concluded that significant predictor factor on sedimentation and water discharge are shrubs and river shape coefficient.

Keywords---environment physical condition, lindu lake watershed, sedimentation, water discharge.
\end{abstract}

\section{Introduction}

There are various disturbances on watershed ecosystem especially from watershed inhabitants such as human (Jordan \& Benson, 2015; Upadani, 2017; Williams et al., 2016). If the watershed function is disturbed, so the hydrology system as the watershed main function will be disturbed as well, also rainfall catchment, recharge, and water storage will decrease (Nasrullah \& Kartiwa, 2009; Oktarian et al., 2016). That phenomenon will cause excessive water in the rainy season but lack of water in the dry season. Furthermore, it also causes fluctuation of river flow between the dry season and the rainy season which highly different. Hence, if the fluctuation of river flow is very sharp it means watershed is not functioning properly which also means the low quality of watershed (Hirpa, Gebremichael, \& Over, n.d.; Rahman, 2009; Wahid, 2009; Wondzell et al., 2007).

ISSN 2632-9468

Received Jan 20, 2019 / Accepted Jun 18, 2019 / Published Jul 05, 2019 
According to Lukman and Ridwansyah (Lukman \& Ridwansyah, 2003), recent measurable Lindu Lake maximum depth is $72,6 \mathrm{~m}$. There is an indication of $30 \mathrm{~m}$ lake siltation since in 1970 Lindu Lake depth is recorded around $100 \mathrm{~m}$. Siltation is an effect of sedimentation. Based on the condition of Lindu lake sub-watershed, if it is not resolved there might be a worse crisis of land (soil) and water resources in the future because of human activities.

Land use is human intervention whether it is permanently or periodically to fulfill their needs in the form of material or spiritual to the needs of complex land resources. Land use pattern of a particular region can give a depiction of the region economics condition and as an indicator of environmental pollution. Hence, there is an interest to provide wider land to expand basic economy which number is increasing (Agustiningsih et al., 2012; Jie et al., 2010).

Lindu lake sub-watershed has harmed by various human activities which do not pay attention to environmental sustainability principles. Recently, Lindu lake sub-watershed has lost more than 16.000 ha of forest area (Lukman \& Ridwansyah, 2003). The main reason is illegal forest conversion into agricultural land. It causes lake on succession condition where it changes from an aquatic ecosystem to the terrestrial ecosystem. Main physical condition factor which affects watershed management is the climate factor which is rainfall (Ningkeula, 2015; Yan et al., 2015). There are several factors that affect water discharge such as rainfall intensity, deforestation, forest conversion into agricultural land, interception, evaporation and transpiration, wind, also flow velocity (Ahmad, 2014; Handayani \& Indrajaya, 2011; Love et al., 2010; Quyen, Liem, \& Loi, 2014; Wondzell et al., 2007). The amount of river flow fluctuation and sedimentation portrays land use pattern and environment physical condition such as rainfall, watershed area, and river shape coefficient (Berhanu et al., 2015; Duncan et al., 2017). This research aims to know the influence of land use area and environment physical condition on sedimentation and water discharge in Lindu lake sub-watersheds.

\section{Research Method}

The used materials are roll meters, sample bottles, cameras, GPS, hagameter, filter paper, and stationery. This research is conducted with survey and non-experimental method. The variable approach is conducted by field survey. This research started from January until April 2017 which located in the Catchment area of Lindu Lake. Afterward, the sedimentation analysis is conducted in the Laboratory of Soil Science Unit, Faculty of Agriculture, Tadulako University, Palu.

Examined Catchment Area of Lindu Lake

Table 1

Sub-watersheds research

\begin{tabular}{llcr}
\hline \multirow{2}{*}{ No } & \multicolumn{2}{c}{ Sub-watersheds } & \multirow{2}{*}{ Area $\left(\mathrm{km}^{2}\right)$} \\
\cline { 2 - 3 } & \multicolumn{1}{c}{ River Name } & Observation Station & 9,68 \\
\hline 1. & Langko River & P1 & 2.794 \\
2. & Wongkodono River & P2 & 138,04 \\
\hline
\end{tabular}

\section{Research Variable}

The dependent variable in this research is land use area (area of the garden, shrubs, rice field, forest, and settlement) and physical condition of the environment (catchment area, and average annual rainfall) and the independent variables are sedimentations and water discharge (Table 2).

Table 2

Dependent and Independent Variable

\begin{tabular}{clcc}
\hline Variable & \multicolumn{1}{c}{ Sub Variable } & Notation & Unit*) \\
\hline Area of Land Use Pattern & Plantation & $\mathrm{X}_{1}$ & $\%$ \\
& Shrubs & $\mathrm{X}_{2}$ & $\%$ \\
\hline
\end{tabular}




\begin{tabular}{clcc}
\hline & Rice field & $\mathrm{X}_{3}$ & $\%$ \\
& Primary forest & $\mathrm{X}_{4}$ & $\%$ \\
& Secondary forest & $\mathrm{X}_{5}$ & $\mathrm{~km}^{2}$ \\
\hline Environment Physical & Area of sub-watersheds & $\mathrm{X}_{6}$ & $\mathrm{~mm} \mathrm{th}^{-1}$ \\
& Average of rainfall & $\mathrm{X}_{7}$ & $\mathrm{Km}^{2}$ \\
\hline Condition & River shape coefficient & $\mathrm{X}_{8}$ & $\mathrm{Ton} \mathrm{ha}^{-1} \mathrm{th}^{-1}$ \\
\hline Wedimentation & & $\mathrm{Y}_{1}$ & $\mathrm{~m}^{3} / \mathrm{det}$ \\
\hline
\end{tabular}

\section{Data Collection}

Number of Points and Observation Period

a) There are 3 (three) catchments of the observation point, each observation points is measured twice at the edge of the river and middle of the river. Thus, the number of water sample on each 3 observation points is 6 samples on each measurement.

b) For observation period, on each of the points is repeated with an interval 7 days (1 week), so measurement during research is 7 times measurement.

\section{Flow Rate Measurement}

The measurement of river discharge and flow rate uses the direct method with the equation of a buoyancy formula:

$\mathrm{Q}=\mathrm{V} . \mathrm{A}$

Information: $\mathrm{V}=$ Average flow rate $(\mathrm{m} / \mathrm{sec}) ; \mathrm{A}=$ Area of river cross section $\left(\mathrm{m}^{2}\right)$;

$\mathrm{Q}=$ river flow rate $\left(\mathrm{m}^{3} / \mathrm{sec}\right)$

Water Sampling Technique (Floating Sediment)

Water sampling technique by using bottle is a modification of Depth - Integrating Suspended technique. The bottle of sediment sample is made simpler with two holes. The first hole for water sample entry and another one for an air hole.

\section{Floating Sediment Analysis}

The amount of sediment concentrate is determined from sediment sample analysis which using evaporation method with equation:

$\mathrm{C}=\mathrm{x}(b-a) \times 1000(m g / l)$

Information:

$\mathrm{C}=$ Sediment concentrate $(\mathrm{mg} / \mathrm{l})$

$\mathrm{V}=$ Volume of sediment sample $(\mathrm{ml})$

$\mathrm{b}=$ The weight of the cup contains sediment deposition (gram)

$\mathrm{a}=$ The weight of empty cup (gram)

the amount of sediment concentrate and water discharge are determined with equation : Qs $=0,00864 . C$. Q. where Qs = total of sediment (ton/day).

$\mathrm{C}=$ sediment concentrate $(\mathrm{mg} / \mathrm{l})$, and $\mathrm{Q}=$ river flow rate $\left(\mathrm{m}^{3} / \mathrm{second}\right)$

\section{Transported Sediment Value}

The amount of sediment per area is calculated with the equation:

$$
S D R=\frac{\text { Transported Sediment }(Y)}{\text { the amount of erosion }(A)}
$$

Where the determination of erosion amount (a) is obtained from the application of simulation formula USLE which is: $\mathrm{A}=\mathrm{R}$. K. LS. C. P. therefore, transported sediment is obtained with the formula: $\mathrm{Y}=$ SDR/A.

\section{Statistical Analysis}

The used statistical analysis method is the multiple regression model to know the relation of an independent variable $(\mathrm{X})$ with the variable response $(\mathrm{Y})$ 
This research uses the regression equation as follows :

$\mathrm{Y}=\mathrm{a}+\mathrm{b}_{1} \mathrm{X}_{1}+\mathrm{b}_{2} \mathrm{X}_{2}+\mathrm{b}_{3} \mathrm{X}_{3}+\mathrm{b}_{4} \mathrm{X}_{4}+\mathrm{b}_{5} \mathrm{X}_{5}+\mathrm{b}_{6} \mathrm{X}_{6}+\mathrm{b}_{7} \mathrm{X}_{7}+\mathrm{b}_{8}+\mathrm{X}_{8}+\varepsilon \ldots \ldots \ldots \ldots \ldots . . . . . .$.

Where:

$\mathrm{Y}_{1} \quad=$ Sedimentation

$\mathrm{Y}_{2}=$ Water discharge

$\mathrm{X}_{1} \quad=$ Plantation

$\mathrm{X}_{2} \quad=$ Shrubs

$\mathrm{X}_{3} \quad=$ Rice field

$\mathrm{X}_{4} \quad=$ Forest

$\mathrm{X}_{5} \quad=$ Settlement

$\mathrm{X}_{6} \quad=$ Sub-watershed

$\mathrm{X}_{7} \quad=$ Average of rainfall

$\mathrm{X}_{8} \quad=$ River shape coefficient

$\mathrm{a}=$ Constants value

$\mathrm{b}(1-5)=$ Regression coefficient value

$\varepsilon=$ Error

\section{Results and Analysis}

Table 3 shows the river with the highest water discharge is Kati river (P3) with average $10,0 \mathrm{~m}^{3} / \mathrm{sec}$ when it is not raining and after raining it becomes $24,58 \mathrm{~m}^{3} / \mathrm{sec}$. Meanwhile, the smallest water discharge is on Wongkodono river (P2) $0,125 \mathrm{~m}^{3} / \mathrm{sec}$ when it is not raining and after raining it becomes $1,25 \mathrm{~m}^{3} / \mathrm{sec}$.

Table 3

River Water Discharge Based on Rainfall Period during Research

\begin{tabular}{ccccccccc}
\hline River Name & \multicolumn{8}{c}{ Water Discharge $\left(\mathrm{m}^{3} / \mathrm{sec}\right)$} \\
\cline { 2 - 8 } & \multicolumn{9}{c}{ Not Raining } & \multicolumn{4}{c}{ After Raining } \\
\cline { 2 - 8 } & 1 & 2 & 3 & 4 & 1 & 2 & 3 & 4 \\
\hline Langko (P1) & 0.4 & 0.5 & 0.6 & 0.9 & 1.1 & 1.2 & 7.2 & 1.1 \\
Wongkodono (P2) & 0.1 & 0.2 & 0.1 & 0.1 & 0.5 & 0.5 & 3.6 & 0.4 \\
Kati (P3) & 6.8 & 6.8 & 13.7 & 12.7 & 15.1 & 15.6 & 52.5 & 15.1 \\
\hline
\end{tabular}

Table 4 Shows River with the largest sedimentation is Kati River (P3) with average sedimentation value (when raining or after raining) in the amount of $165 \mathrm{mg} / \mathrm{L}$ and the least is in Langko River (P1) with sedimentation average (when raining and after raining) in the amount of $109.42 \mathrm{mg} / \mathrm{L}$.

Table 4

Data of River Sedimentation Based on Rainfall period during Research

\begin{tabular}{ccc}
\hline River Name & Sedimentation $(\mathrm{mg} / \mathrm{L})$ & Information \\
\hline Langko River (P1) & 100 & Not raining \\
& 128 & Not raining \\
& 108 & Raining \\
& 168 & Raining \\
& 126 & Not raining \\
Wongkodono River (P2) & 118 & Not raining \\
& 18 & Raining \\
& 124 & Not raining \\
& 124 & Not raining \\
& 122 & Raining \\
& 144 & Raining \\
& 174 & Not raining \\
& 120 & Not raining
\end{tabular}




\begin{tabular}{ccc} 
& 126 & Raining \\
Kati River (P3) & 144 & Not raining \\
190 & Not raining \\
303 & Raining \\
264 & Raining \\
14 & Not raining \\
56 & Not raining \\
184 & Raining \\
\hline
\end{tabular}

Table 5 shows land use by local inhabitants is garden and rice field. The biggest garden land use is in Langko River (P1) in the amount of $16,91 \%$ and rice field in the amount of $8,78 \%$.

Table 5

Land Use

\begin{tabular}{lcccccc}
\hline \multirow{2}{*}{\multicolumn{1}{c}{ Land Use }} & \multicolumn{2}{c}{ Langko river (P1) } & \multicolumn{2}{c}{$\begin{array}{c}\text { Wongkodono river } \\
(\mathrm{P} 2)\end{array}$} & \multicolumn{2}{c}{ Kati river (P3) } \\
\cline { 2 - 7 } & Area of Ha & $\%$ & Area of Ha & $\%$ & Area of Ha & $\%$ \\
\hline Garden (X1) & 163.73 & 16.91 & 336.76 & 12.06 & 974.31 & 7.06 \\
Shrubs (X2) & 14.75 & 1.52 & 0 & 0 & 46.88 & 0.34 \\
Rice Field (X3) & 84.98 & 8.78 & 112.41 & 4.03 & 116.83 & 0.85 \\
Primary Forest (X4) & 314.08 & 32.43 & $1,662.70$ & 59.56 & $5,396.10$ & 39.07 \\
Secondary Forest (X5) & 390.84 & 40.36 & 678.64 & 24.31 & $7,275.87$ & 52.69 \\
\hline
\end{tabular}

Table 6 shows the largest catchment area is in Kati River (P3) in the amount of 13,809.99 $\mathrm{km}^{2}$ and the smallest in Langko River (P1) in the amount of $968.38 \mathrm{~km}^{2}$. Meanwhile, the average of rainfall is $2.205 .42 \mathrm{~mm} \mathrm{th}^{-1}$ and the biggest river shape coefficient is in Langko River (P1) in the amount of 0.125

Table 6

Environment Physical Condition

\begin{tabular}{|c|c|c|c|c|c|c|}
\hline \multirow[t]{2}{*}{ Environment Physical Condition } & \multicolumn{2}{|c|}{ Langko river (P1) } & \multicolumn{2}{|c|}{$\begin{array}{l}\text { Wongkodono river } \\
\text { (P2) }\end{array}$} & \multicolumn{2}{|c|}{ Kati river (P3) } \\
\hline & Nilai & Satuan & Nilai & Satuan & Nilai & Satuan \\
\hline Catchment Area (X6) & 968.38 & $\mathrm{Km}^{2}$ & $2,790.54$ & $\mathrm{Km}^{2}$ & $13,809.99$ & $\mathrm{Km}^{2}$ \\
\hline Average of Rainfall (X7) & $2,205.42$ & $\mathrm{~mm} \mathrm{th}^{-1}$ & $2,205.42$ & $\mathrm{~mm} \mathrm{th}^{-1}$ & $2,205.42$ & $\mathrm{~mm} \mathrm{th}^{-1}$ \\
\hline River Shape Coefficient (X8) & 0.125 & - & 0.089 & - & 0.036 & - \\
\hline
\end{tabular}

Factors which Influence Sedimentation $\left(Y_{1}\right)$

The result of multiple regression analysis from eight variables, it turns out only two variables which have a significant influence on sedimentation and an equation is obtained as follows:

$\mathrm{Y}_{1}=185,903-0,208 \mathrm{X}_{2}-587,269 \mathrm{X}_{8}$

Where $Y_{1}=$ Sedimentation, $X_{2}=$ shrub, $X_{8}=$ River shape coefficient

The result shows that variables which have a significant effect on the sedimentation process are river shape coefficient and shrubs. The bigger river shape coefficient, sediment will increase in the amount of $587,269 \mathrm{mg} / \mathrm{L}$ as multiple regression calculation has been conducted that Lindu lake watershed has big river shape coefficient so the occurrence of sedimentation is also bigger

Factors which Influence River Flow Rate $\left(Y_{2}\right)$

Multiple regression analysis from eight variables in equation generates only two variables which have a significant influence on the change of measured average flow rate and an equation is obtained as follows:

$\mathrm{Y}_{2}=6,854+0,258 \mathrm{X}_{2}-71,708 \mathrm{X}_{8}$

Where $Y_{2}=$ measured average flow rate, $X_{2}=$ shrubs, $X_{8}=$ river shape coefficient. From regression relation in equation (1) it is obtained a very good $\mathrm{R}^{2}$ which is 1 or $100 \%$ the change of measured flow rate average is related to variables of shrubs and river shape coefficient. 


\section{Discussion}

The result of the research shows the largest shrubs so it will decrease sedimentation and make water discharge higher, each addition of one shrub unit will decrease sediment in the amount of $0,208 \mathrm{mg} / \mathrm{L}$ and affects water discharge the amount of $0,258 \mathrm{~m}^{3} / \mathrm{sec}^{-1}$. Shrubs existence maintains Lindu Lake watershed sustainability in a longterm, so it will prevent the occurrence of the siltation process in Lindu Lake watershed. Nevertheless, water discharge will be high if shrubs less absorb the water. Hence, if the rain pours the water will runoff directly to the river and make water discharge high. Water runoff is an amount of water which flows over the land in the form of canals or creeks and end up gather/flow to the main river.

Shrubs and bushes are an area of dry land which has been overgrown with various heterogeneous and homogeneous natural vegetation which its density is rare until dense (BSN, 2010). In Indonesia, generally, shrubs is a former forest area that does not show any trace of trees cutting down (Savitri \& Pramono, 2017). Generally, shrubs also an unproductive area and was abandoned by farmers. Hydrologically, shrubs have important hydro-orological functions especially to maintain microclimate, soil moisture, and microorganism activity (Makarieva et al., 2018; Ryu et al., 2008). Shrubs in several areas are so wide and usually, it is untouched by farmers' activity so the existence is still original.

Furthermore, the bigger river shape coefficient the smaller water discharge average. Thus, each reduction of one unit river shape coefficient will affect water discharge in the amount of $71,708 \mathrm{~m}^{3} / \mathrm{sec}^{-1}$. When an amount of water in a region increases so the faster time that needed for water to flow. Consequently, water discharge will increase when the rain comes.

The increasing of water discharge after rain comes in several sampling points is still normal. It causes by not very high rainfall when the samples are taken. The highest water discharge after rain is in Kati River in the amount of 52,5 $\mathrm{m}^{3} / \mathrm{sec}$ since there was heavy rain the whole day before the data was taken. That increasing of water discharge will not cause any negative effect on local inhabitants activity especially agricultural activity such as rice field area (Suadnya et al., 2017; Wagner et al., 2009). Moreover, the amount of water discharge will not affect other agricultural activity such as seasonal crops around sampling points.

The amount of water discharge has an effect on the agricultural activity which is the amount of water that enters the agricultural area. If the discharge is too low the lack of water to fulfill agricultural need will possibly happen. In contrast, if the discharge is too high it will give a negative effect to agriculture especially rice field area. Nonetheless, water availability is important to run agricultural activity, and basically, all the crops such as seasonal crops around the research area need more water than annual crops.

\section{Conclusion}

The main factor and predictor on sedimentation and water discharge of Lindu lake watershed are shrubs and river shape coefficient. Hence, land expansion by reducing shrubs can give negative effect in form of siltation and causes damage such as river ecosystem loss and flood because of high sedimentation

\section{Acknowledgments}

Thanks to Agriculture Dean of Tadaluko University and Subdistrict Head of Lindu on research assistance in form of funds and access to conduct this research.

\section{References}

Agustiningsih, D., Sasongko, S. B., \& Sudarno. (2012). Analisis Kualitas Air dan Strategi Pengendalian Pencemaran Air Sungai Blukar Kabupaten Kendal. Jurnal PRESIPITASI, 9(2), 64-71.

Ahmad, S. W. (2014). Hydrology Analysis On Characteristics Of Forest Area Conservation Efforts In Sustainable Water Resources. Biowallacea, 1(2), 97-106.

Berhanu, B., Seleshi, Y., Demisse, S., \& Melesse, A. (2015). Flow Regime Classification and Hydrological Characterization: A Case Study of Ethiopian Rivers. Water, 7(12), 3149-3165. https://doi.org/10.3390/w7063149

BSN. (2010). Klasifikasi penutup lahan (SNI 7645:2010). Badan Standarisasi Nasional.

Duncan, J. M., Welty, C., Kemper, J. T., Groffman, P. M., \& Band, L. E. (2017). Dynamics of nitrate concentrationdischarge patterns in an urban watershed: DYNAMIC URBAN NITRATE C-Q PATTERNS. Water Resources Research, 53(8), 7349-7365. https://doi.org/10.1002/2017WR020500 
Handayani, W., \& Indrajaya, Y. (2011). The Analysis of Rainfall and Discharge Relationship on Ngatabaru Sub Sub Watershed, Central Sulawesi. Jurnal Penelitian Hutan Dan Konservasi Alam, 8(2), 143-153.

Hirpa, F. A., Gebremichael, M., \& Over, T. M. (n.d.). River flow fluctuation analysis: Effect of watershed area. Water Resources Research, 46(12). https://doi.org/10.1029/2009WR009000

Jie, L., Jing, Y., Wang, Y., \& Shu-xia, Y. (2010). Environmental Impact Assessment of Land Use Planning in Wuhan City Based on Ecological Suitability Analysis. Procedia Environmental Sciences, 2, 185-191. https://doi.org/10.1016/j.proenv.2010.10.022

Jordan, S. J., \& Benson, W. H. (2015). Sustainable Watersheds: Integrating Ecosystem Services and Public Health. Environmental Health Insights, 9(Suppl 2), 1-7. https://doi.org/10.4137/EHI.S19586

Love, D., Uhlenbrook, S., Corzo-Perez, G., Twomlow, S., \& van der Zaag, P. (2010). Rainfall-interceptionevaporation-runoff relationships in a semi-arid catchment, northern Limpopo basin, Zimbabwe. Hydrological Sciences Journal, 55(5), 687-703. https://doi.org/10.1080/02626667.2010.494010

Lukman, \& Ridwansyah. (2003). Kondisi Daerah Tangkapan Dan Cirri Morfometri Danau Lindu. Oseanologi \& Limnologi Indonesia, 35, 11-20.

Makarieva, O., Nesterova, N., Lebedeva, L., \& Sushansky, S. (2018). Water balance and hydrology research in a mountainous permafrost watershed in upland streams of the Kolyma River, Russia: a database from the Kolyma Water-Balance Station, 1948-1997. Earth System Science Data, 10(2), 689-710. https://doi.org/10.5194/essd-10689-2018

Nasrullah, \& Kartiwa, B. (2009). Hydrological Model of Upstream Aih Tripe Watershed for Drought and Flood Prediction. Jurnal Tanah Dan Iklim, 29, 35-52.

Ningkeula, E. S. (2015). Analisis Karakteristik Meteorologi Dan Morfologi DAS Wai Samal Kecamatan Seram Utara Timur Kobi Kabupaten Maluku Tengah. Jurnal Ilmiah Agribisnis Dan Perikanan, 8(2), 81-91.

Oktarian, D., Liesnoor, D., \& Setyaningsih, W. (2016). Analisis Spasial Perubahan Penggunaan Lahan Di DAS Babon Hulu Terhadap Debit Puncak Sungai Babon Jawa Tengah. Universitas Negeri Semarang, Semarang.

Quyen, N. T. N., Liem, N. D., \& Loi, N. K. (2014). Effect of land use change on water discharge in Srepok watershed, Central Highland, Viet Nam. International Soil and Water Conservation Research, 2(3), 74-86. https://doi.org/10.1016/S2095-6339(15)30025-3

Rahman, A. (2009). The Influence of The Area of Land Use Patterns and Physical Environment Condition on Water Debit and Sedimentation at Various Catchment Areas in The Upper Cimanuk Sub Watershed West Java. $J$. Agroland, 16(3), 224-230.

Ryu, Y., Baldocchi, D. D., Ma, S., \& Hehn, T. (2008). Interannual variability of evapotranspiration and energy exchange over an annual grassland in California. Journal of Geophysical Research, 113(D9). https://doi.org/10.1029/2007JD009263

Savitri, E., \& Pramono, I. B. (2017). Reklasifikasi Peta Penutupan Lahan untuk Meningkatkan Akurasi Kerentanan Lahan. Jurnal Wilayah Dan Lingkungan, 5(2), 83. https://doi.org/10.14710/jwl.5.2.83-94

Suadnya, D. P., Sumarauw, J. S. F., \& Mananoma, T. (2017). Analisis Debit Banjir dan Tinggi Muka Air Banjir Sungai Sario Di Titik Kawasan Citraland. Jurnal Sipil Statik, 5(3), 143-150.

Upadani, I. G. A. . (2017). Model Pemanfaatan Modal Sosial Dalam Pemberdayaan Masyarakat Pedesaan Mengelola Daerah Aliran Sungai (DAS) Di Bali. Wicaksana, Jurnal Lingkungan \& Pembangunan, 1(1), 11-22.

Wagner, K., Neuwirth, J., \& Janetschek, H. (2009). Flood risk - Prevention and Impact on Agricultural Lands. In The 83rd Annual Conference of the Agricultural Economics Society (pp. 1-7). Dublin: The Agricultural Economics Society.

Wahid, A. (2009). Analisis Faktor-Faktor Yang Mempengaruhi Debit Sungai Mamasa. Jurnal SMARTek, 7(3), 204218.

Williams, C. J., Frost, P. C., Morales-Williams, A. M., Larson, J. H., Richardson, W. B., Chiandet, A. S., \& Xenopoulos, M. A. (2016). Human activities cause distinct dissolved organic matter composition across freshwater ecosystems. Global Change Biology, 22(2), 613-626. https://doi.org/10.1111/gcb.13094

Wondzell, S. M., Gooseff, M. N., \& McGlynn, B. L. (2007). Flow velocity and the hydrologic behavior of streams during baseflow. Geophysical Research Letters, 34(24). https://doi.org/10.1029/2007GL031256

Yan, Q., Lei, T., Yuan, C., Lei, Q., Yang, X., Zhang, M., ... An, L. (2015). Effects of watershed management practices on the relationships among rainfall, runoff, and sediment delivery in the hilly-gully region of the Loess Plateau in China. Geomorphology, 228, 735-745. https://doi.org/10.1016/j.geomorph.2014.10.015 